Annals of Warsaw University of Life Sciences - SGGW

Land Reclamation No 44 (1), 2012: 75-88

(Ann. Warsaw Univ. of Life Sci. - SGGW, Land Reclam. 44 (1), 2012)

\title{
Anthropogenic waste products utilization for old landfills rehabilitation
}

\author{
EUGENIUSZ KODA
}

Department of Geotechnical Engineering, Warsaw University of Life Sciences - SGGW

\begin{abstract}
Anthropogenic waste products utilization for old landfills rehabilitation. The paper presents remedial problems of old large sanitary landfills, particularly of embankments type. One of the main problems on a such kind landfills is to secure slope stability. The stability reinforcement methods consist of retaining walls, berms (constructed with selected waste materials), geogrids and mattress constructed of scraped tires. Metallurgical slag backfill material can be used for filters protection of leachate drainage and for technological roads construction on the landfill. The applied slope reinforcements and assurance of the proper performance of the leachate drainage in the landfill are of the greatest importance for the landfill slope stability and further use of landfill areas. Above mentioned aspects are described on the example of large landfill, localized nearby Warsaw. Radiowo landfill was founded in 1962, and now is at the end of the period of its operating and therefore remedial works have been undertaken there. In the future Radiowo landfill area will be adopted for recreation and sports purposes (view points, skiing, cycle roads etc.).
\end{abstract}

Key words: landfills; recycling; slope stability; leachate drainage, erosion protection.

\section{INTRODUCTION}

The problem of rehabilitation of old landfills is start discussed since the 1990 (Daniel 1993; Jessberger et al. 1993) and still is actual (Gourc 2010; Katsumi et al. 2010; Birle et al. 2010). Earlier, the man- agement of such sites usually focused on covering the waste with a layer of randomly collected soil, without attention paid to the principle rules of earth works. Presently, remedial works are understood as a series of engineering and biological activities, related to complete removal of the hazards posed by the landfills on the surrounding environment. Proper remedial works should begin already at the stage of landfill exploitation (Koda 1999, 2011).

Remedial works on old landfills can utilize various types of waste products, such as: ballast wastes and debris for the formation of slopes and roads stabilization, used tires for reinforcements improving the stability of slopes and protection against erosion, diluted leachates for plants irrigation and technological roads spraying, debris and aggregate for filter and drainage layers, as well as compost from waste for the remediation cover on the landfill surface. An example of utilizing such waste materials in the rehabilitation of Radiowo landfill, is presented. Table 1 presents particular sites within the landfill where the particular waste materials have been applied in the remediation process. 


\section{INVESTIGATION AND DESIGN OF LANDFILL REHABILITATION}

The basic waste disposal surveys in old landfills for remediation purposes should include:

- Analysis of exploitation documentation (if existing), defining the kind and age of wastes, as well as unpredictable events (fire, landslides, dangerous wastes, etc.),

- Waste disposal quantity survey, using GPS equipment,

- Recognition of hydrogeological conditions in the landfill basement and its vicinity,

- Analysis of soil, surface and groundwater pollutants ("background"),

- Evaluation of the state and mechanical parameters of wastes,

- Description of protected areas and objects in the landfill vicinity,

- Assessment of the composition and volume of the produced landfill biogas.

Remedial works on old landfill often require exceptional solutions with regard to hydrogeology, sanitary engineering, geotechnics and land management (Koda 2011). Due to the variability of physiographic and hydrogeological conditions, particular projects should not be applied to different objects without earlier interpretation of survey data.

According to the project, typical remedial works on the Radiowo landfill site (old embankment type landfill) include:

- Modernization of the melioration system in the area surrounding of the landfill,

- Construction of a bentonite vertical barrier surrounding landfill (lateral isolation),

- Construction of "finger" drains intake leachates from bottom of landfill berm, drainage on the slopes, peripheral drainage and reservoir trenches around the landfill,

- Construction of a recirculation system of leachate and rainwater from the compostory (retention reservoirs, pump stations, micro-irrigation system),

- Shaping of the landfill by non-composted wastes, including construction

TABLE 1. Specification of waste products applied for the rehabilitation Radiowo landfill

\begin{tabular}{|l|c|c|}
\hline Waste material & Purpose of application & Site of utilisation \\
\hline Ballast wastes & $\begin{array}{c}\text { Slope reinforcement, shaping } \\
\text { the landfill body }\end{array}$ & Berms \\
\hline Used tires & $\begin{array}{c}\text { Horizontal reinforcement } \\
\text { mattresses }\end{array}$ & $\begin{array}{c}\text { Landfill body near slopes, } \\
\text { slopes within the landfill }\end{array}$ \\
\hline Aggregate from steel slag & Filter layer, road aggregate & $\begin{array}{c}\text { Drainage cover, technological } \\
\text { roads for heavy equipment }\end{array}$ \\
\hline $\begin{array}{l}\text { Building debris, crushed ballast } \\
\text { wastes }\end{array}$ & $\begin{array}{c}\text { Road aggregate } \\
\text { Wechnological roads }\end{array}$ \\
\hline $\begin{array}{l}\text { Waste compost } \\
\text { rainwater }\end{array}$ & $\begin{array}{c}\text { Remediation layer, grass } \\
\text { 'carpets' }\end{array}$ & Landfill slopes and crown \\
\hline \multicolumn{2}{|c|}{ lation } & Landfill slopes and crown \\
\hline
\end{tabular}


of berms and mattresses from used tires for the improvement of slope stability,

- Construction of main entrance road to the landfill with elements of road safety,

- Construction of technological roads at the base of the landfill and on the technological plates on the slopes,

- Isolation of the landfill surface (mineral cohesive soil layer),

- Formation of the surface remediation layer from compost made of municipal wastes,

- Introduction of selected vegetation on the landfill surface.

The most of above mentioned construction were built with the use of waste products, specified in Table 1.

\section{SLOPE REINFORCEMENTS USING WASTE PRODUCTS}

The landfill slopes should have an inclination at $1: 3 \div 1: 2.5$, what assumes the stability of introducing vegetation on their surface (Koda and Głażewski 2006). In the case of old landfills, the slope gradients were not controlled, therefore landslides often occur on them, causing expansion of the landfill on the neighbouring area.

In the case landfill threat, activities should be undertaken to improve the stability. The most common methods of improving the slope stability include:

- Decrease of slope inclination (when there is enough space area at the base of landfill),

- Retaining walls, crib buttresses or berms constructed with non-composted wastes,
- Constructions made of reinforced soil (e.g.: geogrids, horizontal reinforcements, also with the use of tyre mattress).

One of the main assumptions in the remediation of the Radiowo landfill with non-composted wastes was assertion of slope stability. Due to the close vicinity of a street, the northern slope was supported by a retaining wall; locally the slope inclination was limited, and in the upper part it was reinforced with five horizontal geogrid layers.

From the west, the landfill lies adjacent to a side-track of the Warsaw Steelworks. Additionally, a gas pipeline is located near the slope base. The slope gradient was 1:1.28 at a height of ca. $60 \mathrm{~m}$, which favoured the formation of landslides. Due to restricted area in the vicinity of the landfill, the lower part of the slope was reinforced by a berm, and the upper part - by a single layer of geogrid PE and three layers of mattresses made of used tires (Figs. 1 and 2). To assure the required resistance, eight reels of PP tape were used for each tire connection. Such solutions are often used in geotechnical practice (Audeoud et al. 1990; Dembicki et al. 1994; Horodecka et al. 2002). A drainage layer with a return-filter grain size was constructed in the base of the berm in order to remove leachates from the landfill base, and the outer layer of the berm was constructed from cohesive soil acting as a mineral sealing of the landfill cover. The scheme of the stability analysis for the landfill slope is presented in Figure 3.

From the east and south, the landfill slopes were reinforced by berms constructed with waste materials (Figs. 4 and 5). Berm construction allows to ob- 


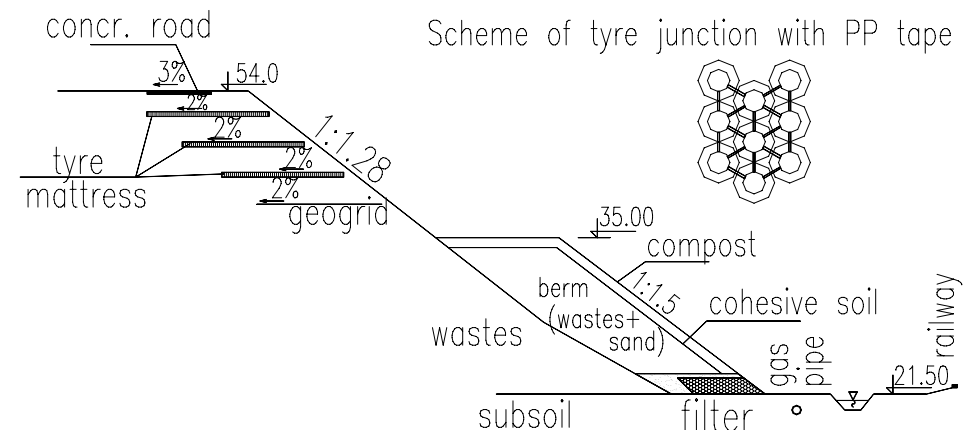

FIGURE 1. The western cross-section of the landfill slope with reinforcements

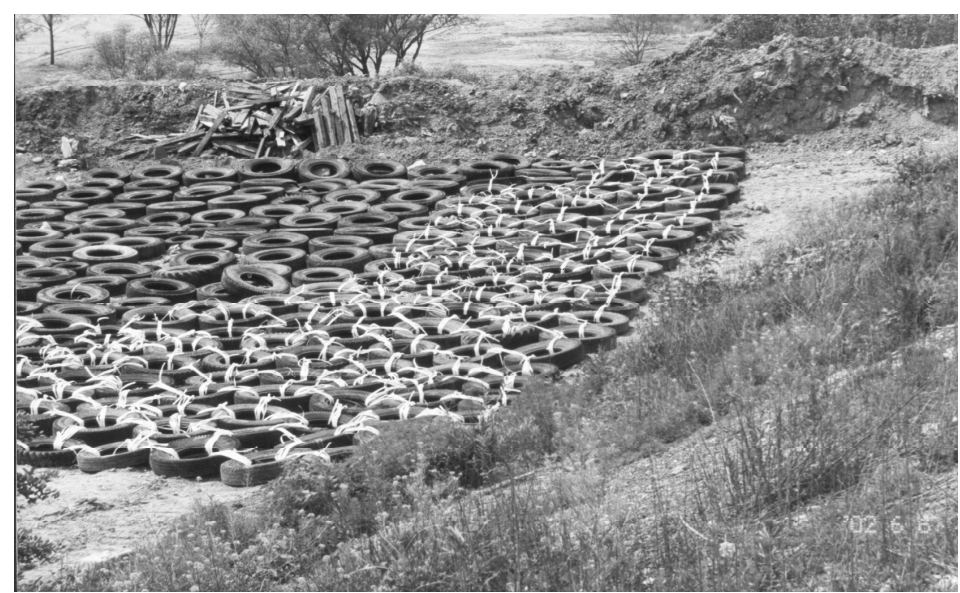

FIGURE 2. Preparation of mattresses made of used tires to reinforce of western landfill slope

tain additional volume for the buildingin of wastes, which is an advantage with regard to the diminishing space for new landfill localizations. The applied reinforcements and assurance of the proper performance of the leachate drainage in the central part of Radiowo landfill are of the greatest importance for the slope stability. The stability factors of reinforced slopes are higher than 1,3.

\section{DRAINAGE AND FILTER LAYERS IN LEACHATE RECIRCULATION SYSTEM}

Capture and management of leachates from the landfill is, beside isolation, one of the most important systems ensuring the protection of the soil-water environment. Usually, mineral (aggregates, stoneware) or artificial materials (pipes, geotextiles), selected on the basis of hy- 


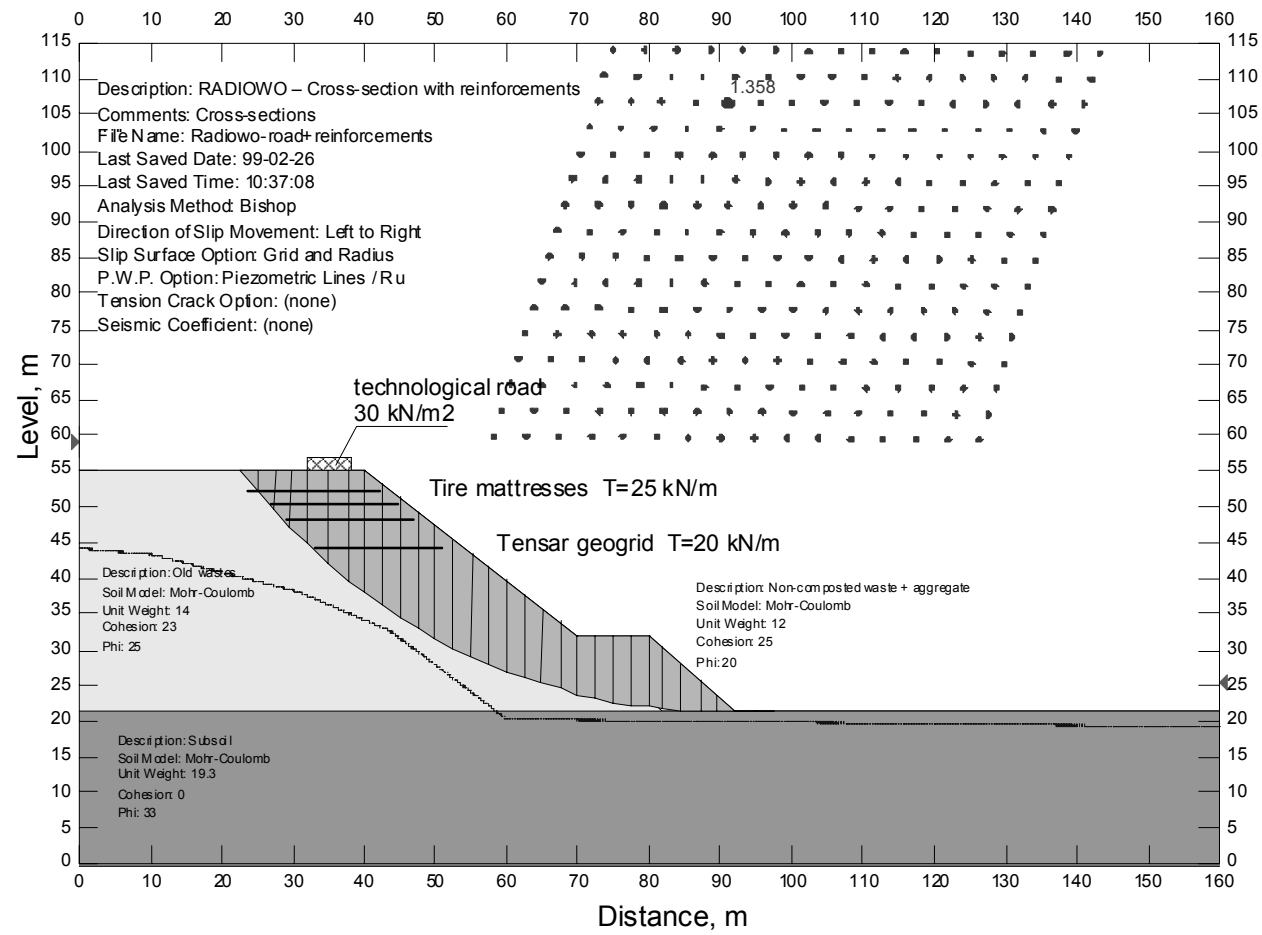

FIGURE 3. Stability analysis of the western landfill slope reinforced by berm and lateral mattress (calculation using Geo-SLOPE numerical program)

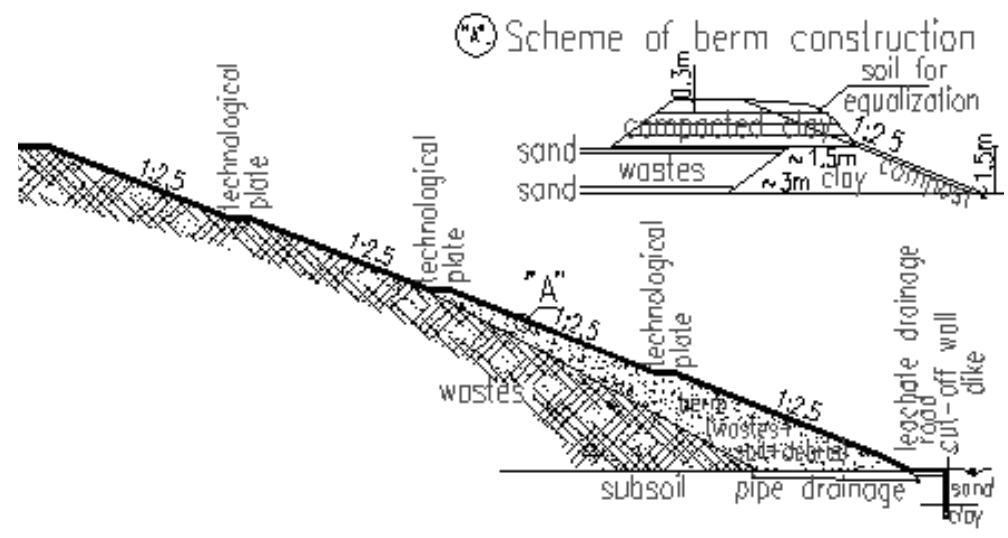

FIGURE 4. The cross-section of the landfill slope reinforced by berm constructed with waste materials 


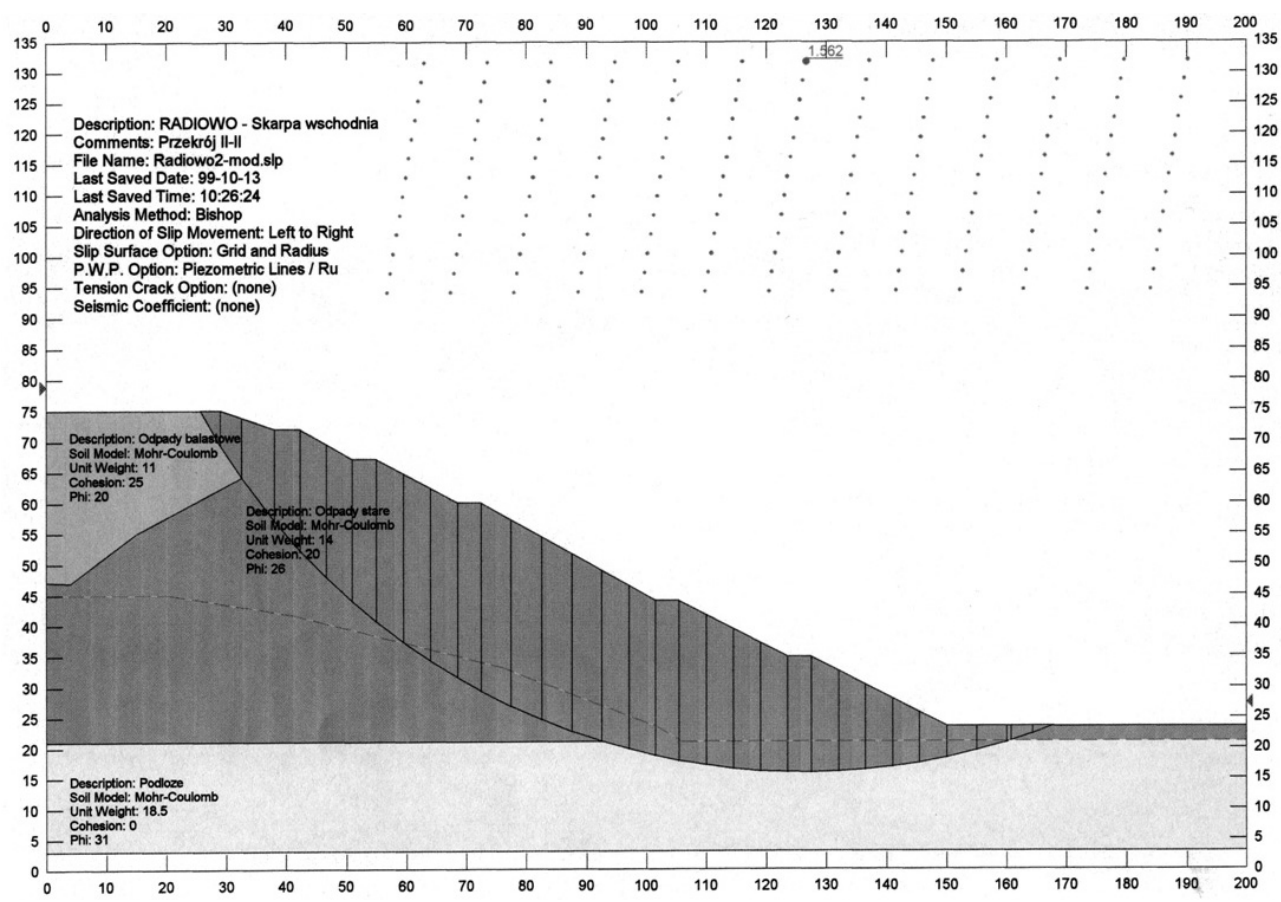

FIGURE 5. Stability analysis of the eastern landfill slope reinforced by berm constructed with selected wastes

draulic criteria, permeability and clogging resistance, are used for the construction of drainage and filtration systems (Koda and Paprocki 2000). Waste materials such as sands from filtration deposits, aggregates from steel slags, and selected building debris can also be applied as filters. Figure 6 shows an example of using sand from filtration deposits from a water supply station and aggregate from steel slag for filters protecting drainages. The filter from steel aggregate is also a route for heavy equipment, which usually cause deterioration of slabs.

In Radiowo landfill, due to management of leachates and rainwater from the compostory in a recirculation system, peripheral drainage has been replaced by trenches reservoirs, to which lead "fin- ger" drains leading leachates from the base of berms. A scheme of the groundwater protection system constructed around the landfill at the slope base is presented in Figure 7. The plan of the landfill site management with drainage elements and system of leachate recirculation is presented in Figure 8. The main element of this system is a leak-tight basin in the landfill crown (Fig. 9), from which water is pumped on the surface. The total volume of retention reservoirs for leachates in the recirculation system reaches ca. $8000 \mathrm{~m}^{3}$. The surface of the landfill has been sub-divided into zones with different water retaining capacity (Fig. 8) in order to select relevant irrigation doses. Leachates on the landfill surface are distributed with the application 


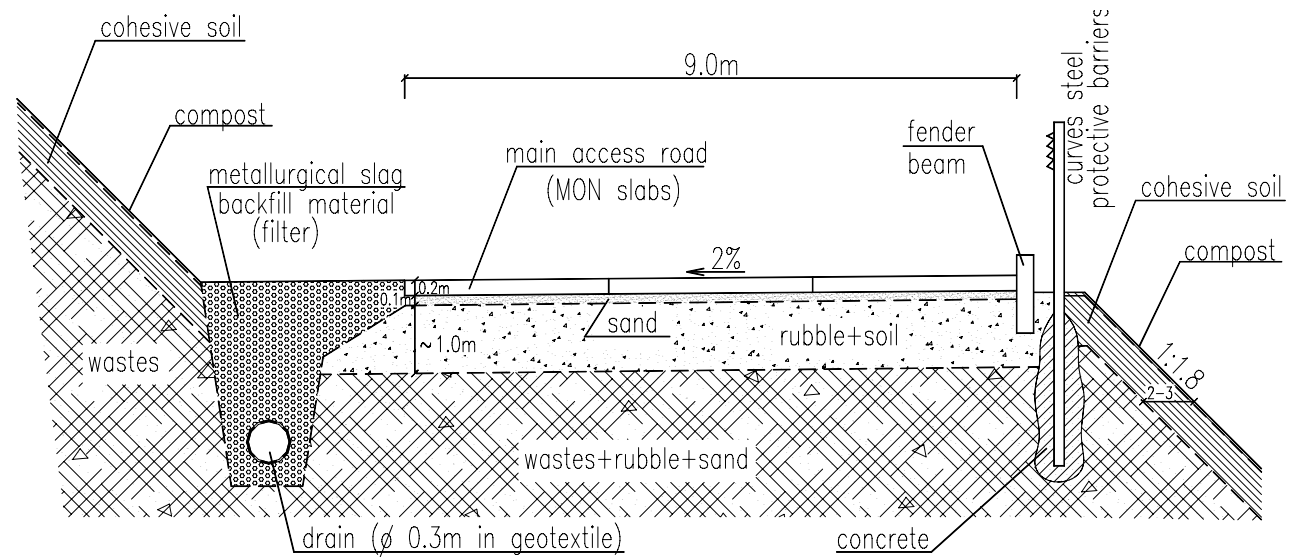

FIGURE 6. Cross-section of the substructure of the main entrance road to the landfill

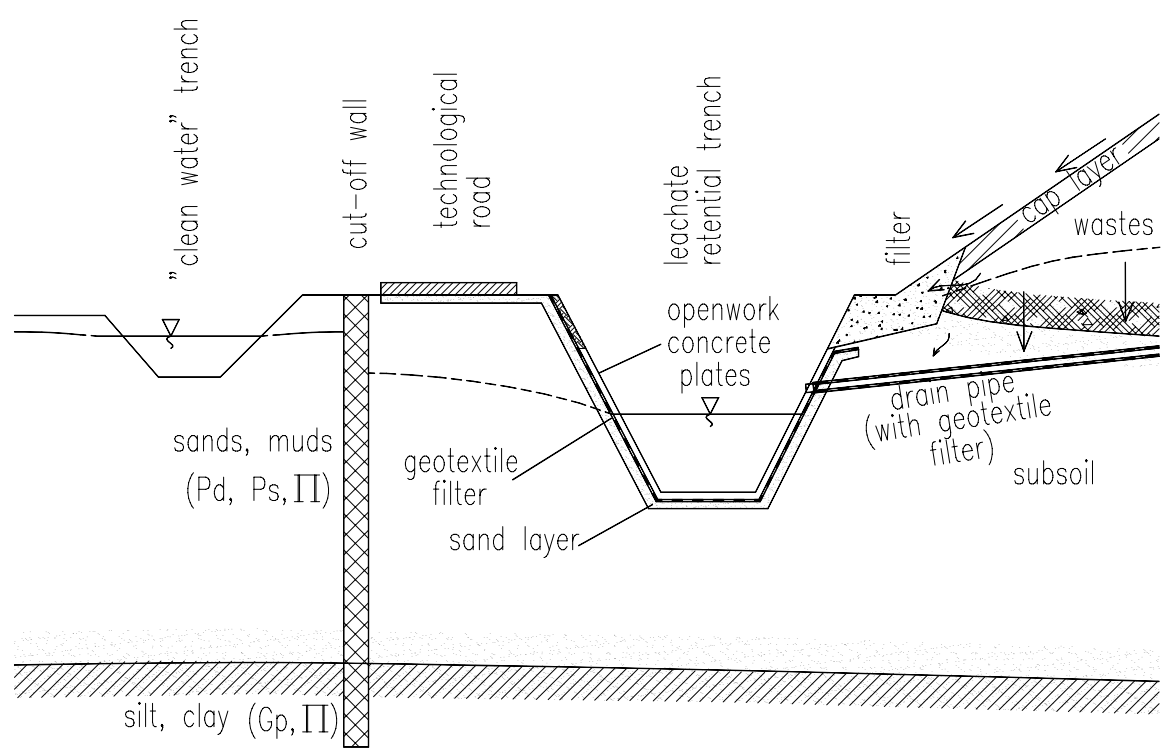

FIGURE 7. The groundwater protection system against leachate in Radiowo landfill

of infiltration-vaporiser reservoirs, portable systems of rain water irrigation and a micro-irrigation system. The leachate recirculation system is exploited in the landfill site since the late 1990s (Koda and Żakowicz 1998). In this period there were no significant surplus leachates in relation to the forecasted water balance of the landfill.

\section{PLANT COVER \\ IMPLEMENTATIONS \\ ON THE LANDFILL SURFACE}

Beside the applied and planned technical remedial works, it is also essential to introduce a vegetation cover on the landfill (biological remediation). The plant species introduced on the landfill surface 


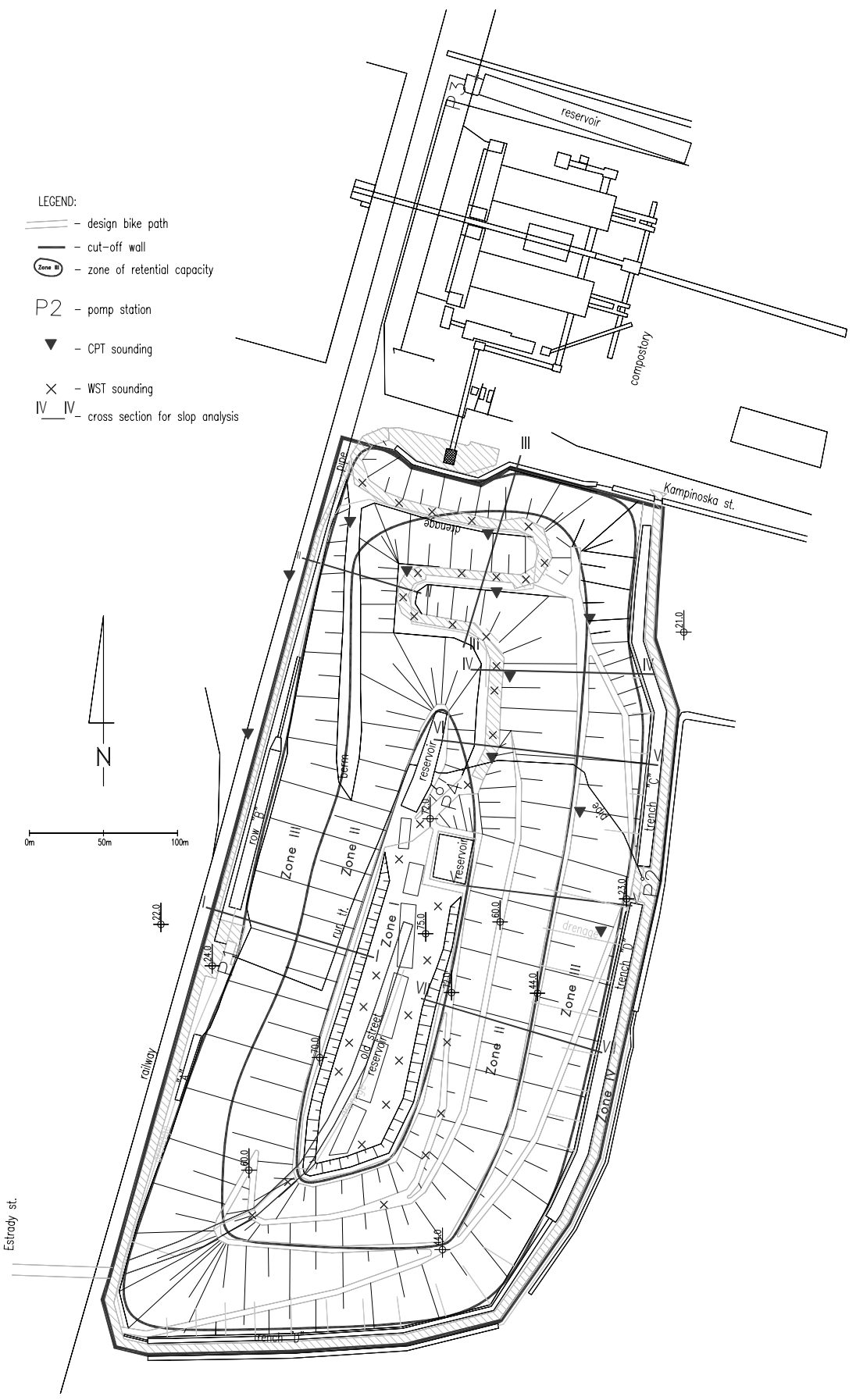

FIGURE 8. The plan of Radiowo landfill with drainage and leachate recirculation systems and zones with different water retaining capacity for defining irrigation doses 


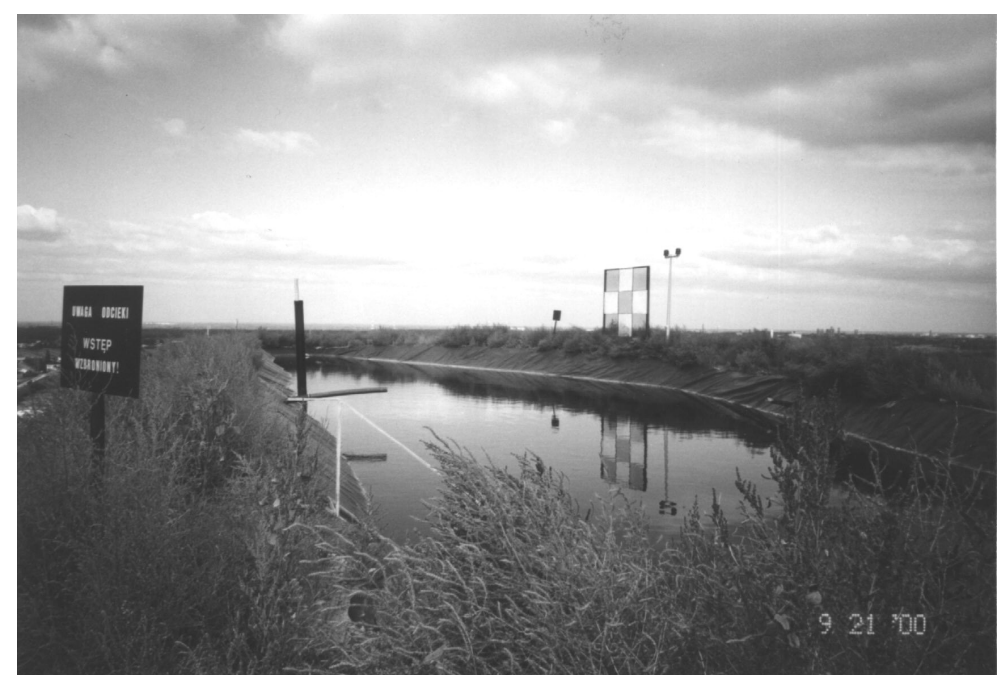

FIGURE 9. The leak-tight basin for leachate recirculation in the landfill surface

and the protected zone should be characterized by the following properties $(\mathrm{Pa}-$ chuta and Koda 2004):

- ecological, i.e. resistance to toxic gas exhalations from the landfill, expansiveness and competition in relation to the existing species, etc.,

- biological, i.e. large biomass increase and high transpiration, formation of diverse settlings, easy spreading, well-developed root system and good coverage of the area for erosion protection,

- economical, i.e. available plant material, low costs of gaining seeds and seedlings and their implantation in conditions of continuous watering, etc.

The scale of this event and the complexity of problems linked with the utilization of municipal waste and landfill remediation require the application of interdisciplinary technical and biological solutions. Complex methods of landfill remediation include:

- groundwater protection against pollution on areas adjacent to the landfill, e.g. through construction of cut-off walls barrier,

- landfill body formation ensuring the stability of slopes, formation of a mineral cover system ensuring conditions for the introduction of vegetation,

- utilization of compost produced from waste for covering landfill slopes,

- construction of leachates capturing and management or remediation system,

- planting and sowing the landfill surface with selected plant species,

- utilization of diluted leachates for irrigation of vegetation growing on the landfill,

- leachate recirculation to increase water evaporation,

- selection of plant species for ecological management of the landfill area and its protection zone, proposal of enrichment of the vegetation in the protection zone with application of existing biological potential and habitat conditions. 
Plant species most resistant to the unfavourable environmental conditions are those whose representatives have spontaneously appeared on the slopes. A survey of the vascular plants growing on the landfill and in its protected area supplied data for the selection of species adapted for growth in this environment (Fig. 10). ing and hydraulic properties, as well as assure the slope protection against erosion. The porous structure of the geotextile or geogrid allows easy penetration of plant root systems to the mineral cover layer. Selection of reinforcing material was based on its mechanical properties and source material for its production.

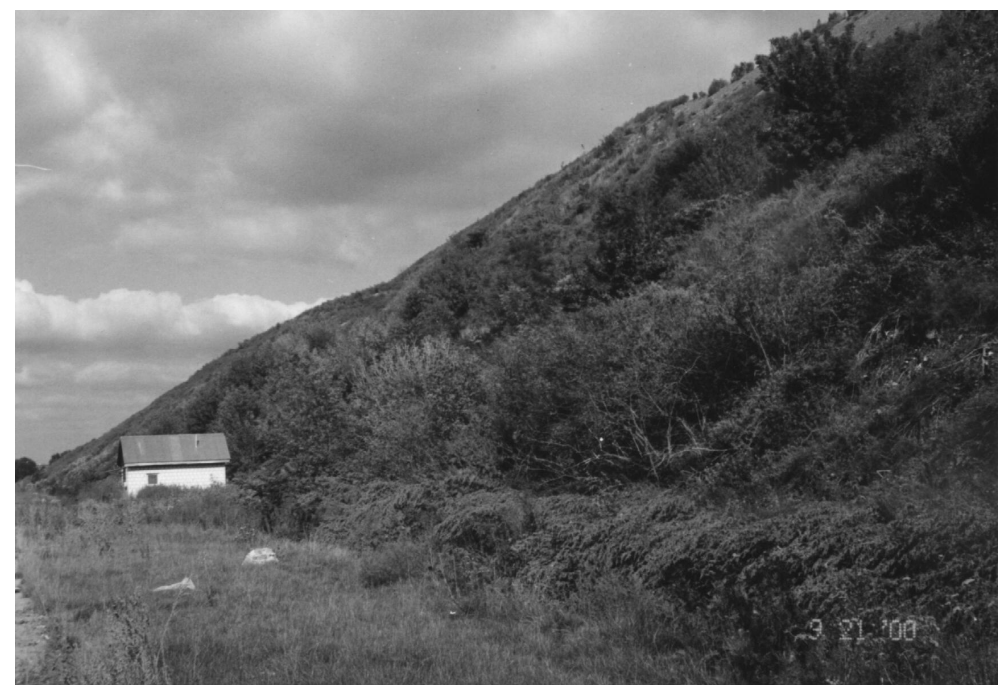

FIGURE 10. Vegetation on the western slope of the landfill

An experimental field was installed in the Radiowo compostory in order to assess the possibility of using compost from municipal wastes to produce grass compost-geotextile carpets (Krzywosz and Koda 1997). The field was localized on concrete place, where an experimental production of geo-composite (grass carpet) was commenced. The grass carpet was composed of three main elements: reinforcing material, substrate and specific selection of grass species. The reinforcing material included needled geotextile (G) and geogrid (Gs) with selected physical, hydraulic and mechanical parameters. Geosynthetic reinforcement is supposed to link the particular elements of the grass carpet, increase its reinforc-
Application of polypropylene guarantees long-term maintenance of these properties even in the aggressive environment of a municipal waste landfill. Three groups of ready-made grass seed mixtures were used for sowing on the grass carpets, i.e. lawn type (MT), pasture type (MP) and garden type (G). The substrate was composed of a mixture of sand and enriched compost in a specific ratio. A variation with pure compost was also tested. Compost with the three following volume proportions: $1 \mathrm{~S} / 1 \mathrm{C}-1: 1$ (1 part sand +1 part compost), $1 \mathrm{~S} / 2 \mathrm{C}$ - 1:2 (1 part sand +2 parts compost) and $\mathrm{C}$ - pure compost (100\% compost) was applied as the substrate. A scheme of the experimental field to produce grass 
carpets is presented in Figure 11. The plants were irrigated with technological water flowing from the compostory plant, which is another advantage due to the fact that they are transported on the protected areas of the Kampinos National Park. Systematic increase of the grass undergrowth was observed. Well-developed root system of the grass carpets was obtained after 6 weeks of field installation. The grass carpets were built-in onto the slopes of the landfill (Fig. 12) for further observation.
Assessment of the sodding state of the landfill slopes were carried out after 1 , 2 and 6 years, after the carpet buildingin. Despite the change in the taxonomic composition of the plant assemblage, the experimental slope is characterized by even and dense sodding, significantly better than the slopes covered with traditional vegetation. This type of vegetation is the first stage of the formation of a succession of stable plant communities on the slopes of the remediated landfill. The slope is stable after ten years of grass carpets existence.

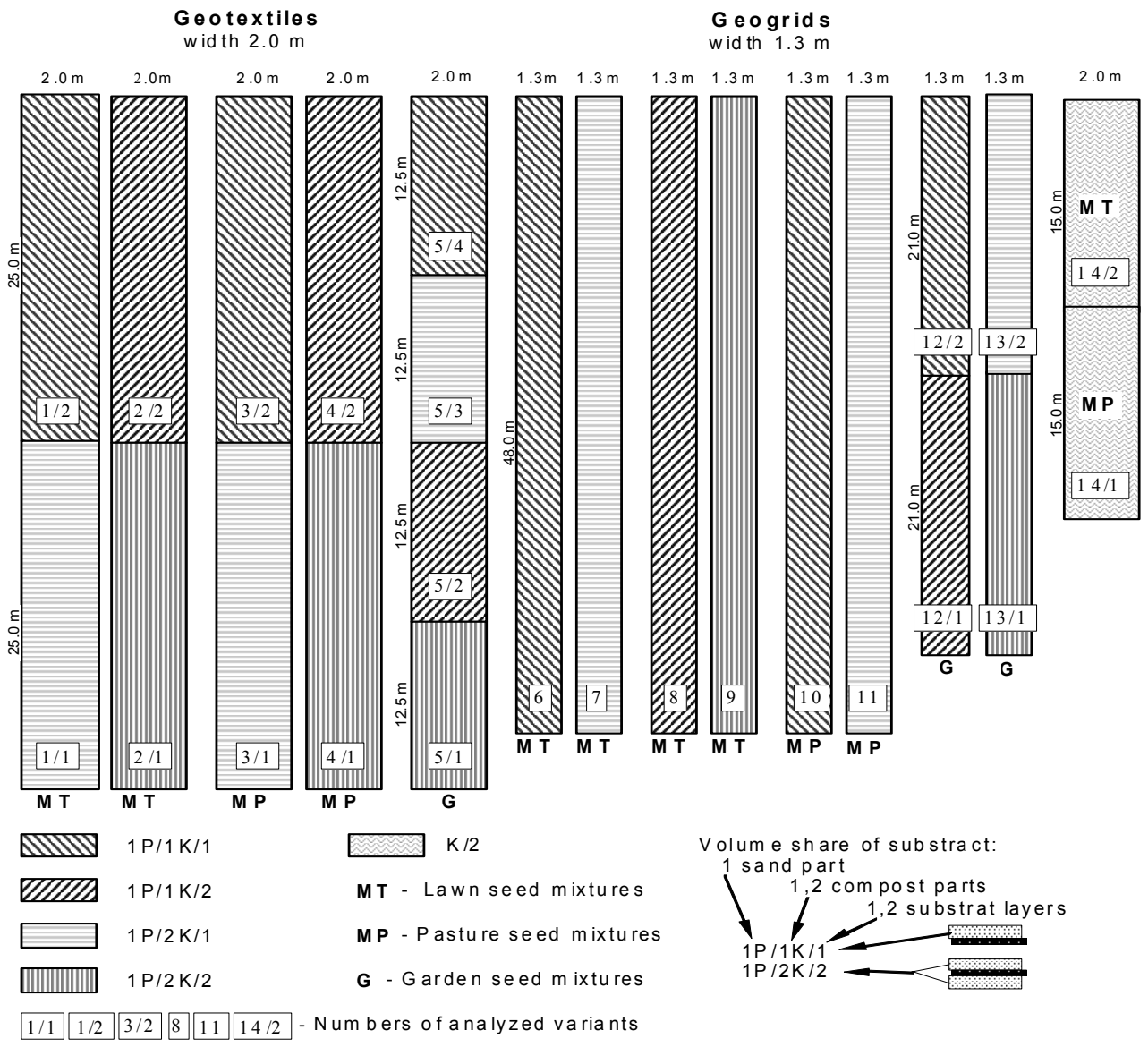

FIGURE 11. Scheme of the experimental field for grass carpets with waste compost utilization 


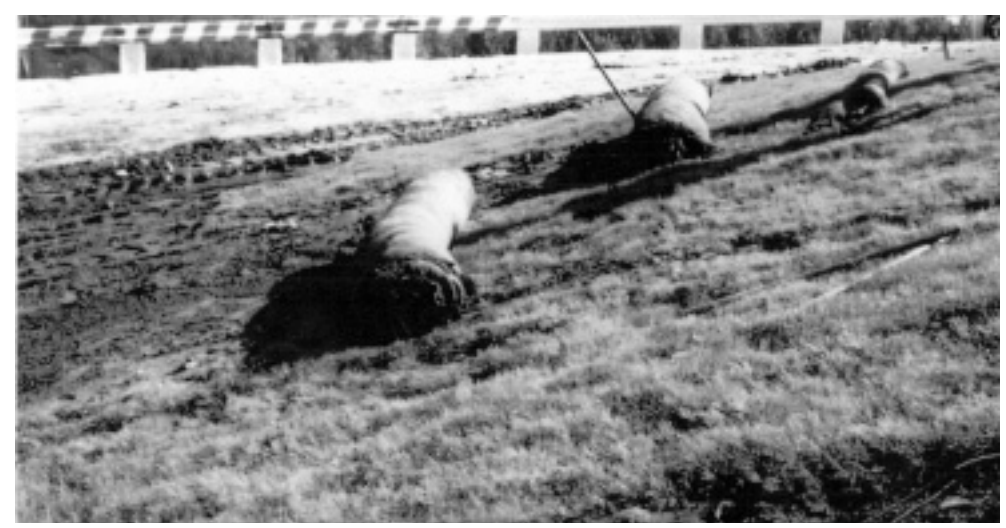

FIGURE 12. Grass carpets introduction into the landfill slopes

\section{CONCLUSIONS}

- Rehabilitation of old landfill sites is a usually a long-term process, requiring non-conventional and complex technical as well as biological activities. Waste material can be effectively used in the remedial works.

- Stability of the high slopes of embankment landfills is assured by the formation of berms with application of ballast wastes, debris and waste soils. This solution allows to obtain additional capacity to waste disposal. Lateral reinforcements of the landfill slopes and protection against erosion are assured by the application of mattresses made of used car tires.

- Filter layers and leachate drainage can be made with application of waste aggregates such as: utilized deposits for water filtering, aggregates from steel slags and crushed debris, in the case when permeability and clogging resistance criteria are fulfilled.

- Compost from municipal wastes is a good substitute of humus to form a remediation layer on the landfill surface. Better sodding and formation of undergrowth is obtained by the utilization of compost in the production of grass carpets reinforced with geotextiles. Grass carpets are good protection of the slopes against erosion and allow a succession of stable plant cover.

- Irrigation of the vegetation on the landfill slopes and technological roads in dry periods can be accomplished by using diluted leachates, managed in the recirculation systems.

- Proper application of waste materials proves the high effectiveness of remedial works and effectively reduces costs of activities undertaken.

\section{REFERENCES}

AUDEOUD B. et al. 1990: The Pneusol. Laboratoire Central des Ponts et Chausseas, Paris.

BIRLE E., HETER D., BOSO M. 2010: Technical Safeguards for Earth Construction with Contaminated Soils and Recycled Materials of Low Permeability. Proc. of the 6th International Congress on Environmental Geotechnics, New Delhi, Vol. 1, 1061-1066. 
DANIEL D.E. ed. 1993: Geotechnical practice for waste disposal. Chapman \& Hall, London.

DEMBICKI E., BOLT A., BARTOSZAWICZ A. 1994: Opony samochodowe jako elementy budowli ziemnych. National Conference on Geotechnical Aspects in Waste Disposals. Gdańsk, Vol. I, 381-384 (in Polish).

GOURC J.-P., STAUB M.J. 2010: The Biohydro-mechanical Behaviour of MSW (Municipal Solid Waste) and the Improvement of Landfill Environmental Sustainability. Proc. of the 6th International Congress on Environmental Geotechnics, New Delhi, Vol. 1, 24-39.

HORODECKA R., KALABIŃSKA M., PIŁAT J., RADZISZAWSKI P., SYBILSKI D. 2002: Wykorzystanie zużytych opon samochodowych w budownictwie drogowym. Road and Bridge Research Institute, Vol. 54, Warszawa (in Polish).

JESSBERGER H.J. ed. (ISSMFE/ETC5). 1993: Geotechnics of Landfills Design and Remedial Works - Technical Recommendations GLR. Ernst \& Sohn, Berlin.

KATSUMI T., INUI T., KAMON M. 2010: Sustainable Geotechnics for Reuse of By-Products. Proc. of the 6th International Congress on Environmental Geotechnics, New Delhi, Vol. 1, 302-317.

KODA E. 1999: Remediation of the old embankment sanitary landfills. Geoenvironmental Engineering: Ground Contamination. Thomas Telford ed., London, 29-38.

KODA E. 2004: Stability analysis of old landfill slopes for remedial works. Proc. of the EU GeoEnvNet Seminar "Geoenvironmental Engineering - Transfer of Knowledge and EU' Directives to Newly Associated States". Warsaw, 115-124.

KODA E. 2011: Landfill stability under reclamation and pollutant transport using the observational method. Wydawnictwo SGGW, 275 pp. (in Polish).

KODA E., GŁAŻEWSKI M. 2006: Technical and biological reinforcement of rebuilt landfill slopes. Proc. of the 13th Danube-European Conference on Geo- technical Engineering. Ljubljana, Vol. 2, 275-280.

KODA E., PAPROCKI P. 2000: Durability of leachate drainage systems of old sanitary landfills. Proc. of the 3rd International Conference on Filters and Drainages in Geotechnical and Environmental Engineering, Warsaw, Balkema A.A. ed., 215-222.

KODA E., ŻAKOWICZ S. 1998: Physical and hydraulics properties of the MSW for water balance of the landfill. Proc. of the 3rd International Congress on Environmental Geotechnics, Lisboa, Vol. 1, 217-222.

KRZYWOSZ Z., KODA E. 1997: Biological slope stabilization with the use of grass carpets made of compost from municipal wastes. $3^{\text {rd }}$ Conference on Geotechnical Engineering in Landfill Construction. Pułtusk, 183-194 (in Polish).

PACHUTA K., KODA E. 2004: Selection of plants in the initial stage of landfill reclamation process. Annals of Warsaw Agricultural University - Land Reclamation 35, 29-38.

Streszczenie: Wykorzystanie odpadowych produktów antropogenicznych do rekultywacji starych skladowisk odpadów. Celem prowadzonych prac rekultywacyjnych na składowiskach odpadów jest zapewnienie bezpieczeństwa geotechnicznego oraz wyeliminowanie negatywnego oddziaływania na środowisko i przystosowanie tych obiektów do przyszłego zagospodarowania. Rekultywacja składowisk odpadów jest procesem długotrwałym, stwarzającym możliwości zastosowania nietypowych rozwiązań inżynierskich. Do przeprowadzenia zabiegów rekultywacyjnych na starych składowiskach odpadów mogą być wykorzystane różnego rodzaju materiały antropogeniczne, takie jak: odpady balastowe $\mathrm{z}$ kompostowni i gruz budowlany do kształtowania skarp i stabilizacji dróg technologicznych, zużyte opony samochodowe do wzmocnień poziomych w celu poprawy warunków stateczności skarp i zabezpieczeń przeciwerozyjnych, rozcieńczone odcieki ze składowiska do podlewania roślinności i dróg technologicznych, gruz i kruszywo odpadowe do zasypek filtracyjnych i warstw drenażowych oraz kompost $\mathrm{z}$ odpadów do tworzenia warstwy 
rekultywacyjnej na powierzchni składowiska. W pracy przedstawiono przykłady wykorzystania materiałów antropogenicznych do rekultywacji składowiska Radiowo k/Warszawy. W pracy przedstawiono również doświadczalną produkcję dywanów trawiastych na bazie kompostu wytwarzanego z odpadów, które wykorzystano do stabilizacji i zabezpieczenia przeciwerozyjnego skarpy składowiska. Wykorzystanie materiałów antropogenicznych było uwzględnione w projektach budowlanych rekultywacji i obliczeniach konstrukcyjnych, w tym w analizie stateczności skarp. Omówiono wyniki badań i obliczeń projektowych oraz kilkunastoletnich obserwacji zachowania się konstrukcji inżynierskich wykonanych $\mathrm{z}$ wykorzystaniem materiałów antropogenicznych.
Stowa kluczowe: składowiska, stateczność skarp, drenaże odcieków, ochrona przeciwerozyjna.

MS. received May 2012

Author' adress:

Eugeniusz Koda

Katedra Geoinżynierii

Szkoła Główna Gospodarstwa Wiejskiego

ul. Nowoursynowska 159

02-787 Warszawa

Poland

e-mail: eugeniusz_koda@sggw.pl 